\title{
Anca Peiu: Romantic Renderings of Selfhood in Classic American Literature Bucharest: Editura C.H. Beck, 2017
}

\author{
Review by \\ Aliz FARKAS \\ Sapientia Hungarian University of Transylvania, Cluj-Napoca \\ Department of Human Sciences, Miercurea Ciuc \\ farkasaliz@uni.sapientia.ro
}

Anca Peiu's volume presented in this review comprises essays written on the works of emblematic figures of American literature who created their masterpieces during the $19^{\text {th }}$ century. The writers included in this work represent two basic literary genres, namely fiction and poetry. The species analysed vary from romance, novella, short story, and novel - all belonging to the field of fiction - and various types of poetry ranging from ballads to short, cryptic poems. However, drama is far from being excluded since - as the author points it out in the introduction - all the works selected stem from the writers' "innermost dramatic impulse" (1).

The book is organized into two main parts. The first one, "Selfhood in/or Poetry", discusses selected works of five authors "who laid the foundations of American Poetry" (XIII), namely: Edgar Allan Poe, Ralph Waldo Emerson, Henry David Thoreau, Walt Whitman, and Emily Dickinson. In the second half of the book, "Selfhood in/or Storytelling", the author discusses the works of six prominent story-tellers: Washington Irving, James Fennimore Cooper, Nathaniel Hawthorne, Herman Melville, Mark Twain, and Kate Chopin.

In the foreword to her volume, Anca Peiu reveals the principle that is underlying her inevitably subjective selection of the writers who best represent the main theme of this exigent book: "the quest for and the expression of the (literary) self" (XIII). The most salient features that bring these poets and writers on the same platform in the author's system of values are identified as their constant pursuit of self-teaching, their common language of nonconformity, and their intellectual honesty. These features shared by all of the eleven authors discussed permanently shape their literary and private selves alike, and this constant change is exactly the theme scrutinized by the writer of this book, who postulates selfhood "as a fluid entity, as form of existence always in the making” (1). 
The author sets the framework for the entire volume in the introduction by relying on two decisive moments of American history leaving indelible imprints on the lives, values, and lifework of the writers discussed. The first of these moments was Christopher Columbus's random discovery of a totally unknown continent in October 1492, which changed America's destiny forever. With regard to this first important moment, the author adopts Tzvetan Todorov's portrait of Columbus as depicted in his insightful book The Conquest of America. The Question of the Other. The heroic qualities that Columbus possesses according to Tzvetan Todorov are his fortitude (as an adventurer), his indomitable faith (as a Christian), and his lack of hostility (towards the indigenous people he met on the continent he discovered). With an acute sense of observation, Anca Peiu points out the correspondence existing between these three personal qualities identified by Tzvetan Todorov and the three main preoccupations and challenges that yield $19^{\text {th }}$-century American literature its unique flavour: the Frontier Myth incessantly urging the newcomers to explore further portions of the wilderness invested with a great deal of potential dangers but an even greater amount of eager hopes and expectations; Puritanism as the predominant form of the Christian faith with its profound repercussions on every aspect of the believers' lives and endeavours; and, finally, the interracial tensions flaring up at regular intervals ever since Columbus's arrival and culminating in the abominable institution of chattel slavery.

The other decisive event that marked not only the destiny of the new continent but also the focus and priorities of the writers discussed in the volume was the adoption of The Declaration of Independence on 4 July 1776. One of the most important passages of the document highlighted by Anca Peiu for its relevance to the theme of the present volume specifies the three basic rights of any citizen living on American soil, namely: life, liberty, and the pursuit of happiness. The author singles out this last right (the pursuit of happiness) as the one "which represented the American contribution to the contemporary view upon the meaning of human life" (6). In her view, this detail is the one that best distinguishes the American sense of self, and it is also the prevailing theme entertained by the writers inhabiting the book.

The originality of Anca Peiu's analysis of the works - which in time have become classics of world literature holding the attention of so many scholars and literary critics who, in their turn, have written whole libraries on these masterpieces lies in her comprehensive, multifaceted approach, which engenders multilayered interpretation, bringing to the surface hidden interrelations among the writers and works under scrutiny, among the works included in the volume and other classics of universal culture as diverse in their ways of representation as paintings, music, and films.

The first stage of interpretation is the closest to what we usually envisage when we think of literary analysis: looking closely at the literary text trying to make 
sense of it by decoding the system of symbols used by the writer and interpreting and reframing the findings in the light of the writer's other works, his/her life, and that of the epoch in which the work was created. Anca Peiu makes her own contribution to this level by not being afraid of bypassing mainstream interpretations of the work and by focusing on the details that she finds important but at the same time readily invoking any other literary critic whose observations she unreservedly shares.

The second stratum of interpretation consists in the mapping of correspondences in content and/or tone of the writers and works under discussion, and so the analyses of the different works are not neatly separated from one another by being carried out exclusively in the subchapter bearing the name of a given writer. Rather, a web of cross-references emerges from the pages, created by the author's organizing mind, which makes it possible for her to point out relevant similarities among the literary phenomena under discussion. Thus, the reader can gain an insight into the source of bitter humour shared by Edgar Allan Poe and Mark Twain, the inherently dialogical nature of Ralph Waldo Emerson's prose and Walt Whitman's poetry, or the voluntarily chosen condition of the reclusive rebel assumed by both Emily Dickinson and Herman Melville - to mention just three of the numerous coincidences highlighted by the author.

The third layer of interpretation unfolds from the author's deep knowledge and understanding of other great works of world literature and - as an Eastern European scholar - familiarity with national, more specifically, with Romanian literature. This is how the American Edgar Allan Poe and the Romanian Ion Luca Caragiale are inevitably brought together in the author's mind by virtue of their "shared bitter disappointment with universal human shallowness, meanness, narrow-mindedness, idle conformity to routine, lack of imagination, lack of loyalty, and above all, crass stupidity” (29). With regard to poetry, one of the reasons why Emily Dickinson's refined poetry resonates so well with the author is that it evokes a much appreciated contemporary Romanian poet, Ana Blandiana (183).

But Anca Peiu does not limit herself to scanning the field of literature for perceiving similar phenomena; she is not reluctant to connect literary figures and pieces of music or paintings (Hester Prynn's romance evoking Vivaldi's The Four Seasons and Rembrandt's bold contrasts) or relying on more modern forms of art, such as films, to get her message across as in the following excerpt: "Huck Finn could be also detected at the back of Forrest Gump's (apparently feeble) mind, wondering about the meaning of human life and its chances to the slightest coherence" (320).

An additional layer of interpretation steps out of the realm of literature and that of other forms of art and pertains to life itself, forcing us to reflect upon our everyday petty preoccupations and follies. Centuries may have passed since 
the literary works included in the volume were created, but the human psyche has hardly changed ever since, if at all. Self-pity, so harshly criticized by Ralph Waldo Emerson, is at least as widespread as it used to be in the $19^{\text {th }}$ century, exposing the autonomous modern person for what s/he really is: an avoidant personality refusing to take responsibility for his/her own life, "clinging to others for support" instead (72). The same cowardice manifests itself in our propensity towards imitating others, in our snobbery stemming from conformity, our reluctance to go against the grain even if that would be in accordance with our inner truth and values. And exactly this is the point where the great ancestors - some of which are featured in this volume - can encourage us for "it takes courage to keep up against the mainstream: yet it helps a lot to know that others have been there before" (73).

In the introduction to her volume, Anca Peiu dedicates this collection of essays to her $21^{\text {st }}$-century Romanian university students to serve them as an updated guide in their forays into the realm of American literature. However, after having read it carefully, I consider that the circle of potential readers is much larger than that. Anyone coming from the academic milieu or a layman genuinely interested in $19^{\text {th }}$-century American literature can read this book with a good profit. Generous excerpts from the works under discussion make it easy for the reader to follow the author's train of thought.

Aside from the original texts, there are a number of other components meant to ease the reader's task such as short introductions and closing words at the beginning and at the end of subchapters, short biographies of the writers, a list of literary works analysed in the book, a detailed chronology of the main poetic and political turns of American history, and even fine pencil portraits of the eleven writers included in the volume. And, above all, what really makes this literary time travel worthwhile, there is Anca Peiu's subtle voice at times guiding the reader, at other times inviting him/her to actively participate in the exploration of meanings with her unexpected, puzzling questions directly addressed to the reader. 